\title{
Bio-organic and inorganic fertilizers modify leaf nutrients, essential oil properties, and antioxidant capacity in medic savory (Satureja macrantha L.)
}

\author{
Mitra Bakhtiari, ${ }^{1}$ Hamid Mozafari, ${ }^{1}$ Khalil Karimzadeh Asl, ${ }^{2}$ Behzad Sani, ${ }^{1}$ Mehdi Mirza ${ }^{2}$ \\ ${ }^{1}$ Department of Agronomy, Shahr-e-Qods Branch, Islamic Azad University; ${ }^{2}$ Research Institute of Forests and \\ Rangeland, Agricultural Research, Education and Extension Organization (AREEO) Tehran, Iran
}

\begin{abstract}
The present study was carried out to assess the effects of bio-organic and inorganic fertilizers on plant nutrients, essential oil composition and antioxidant capacity of Satureja macrantha L. The experiment included nine treatments viz., NPK $\left(50: 25: 25 \mathrm{~kg} \mathrm{ha}^{-1}\right)$, Vermicompost (VC) $\left(5 \mathrm{tha}^{-1}\right)$, NPK $+\mathrm{VC}$, Thiobacillus (T), T+VC, T+sulfur (S) $\left(250 \mathrm{~kg} \mathrm{ha}^{-1}\right), \mathrm{T}+\mathrm{S} 500 \mathrm{~kg}$ $\mathrm{ha}^{-1}$, Glomus mosseae, and control (untreated plants). The results showed the highest Essential Oil (EO) content and yield were respectively observed in plants treated with the combination of VC and NPK. Total Phenol Content (TPC) in first-year plants treated with VC and second-year plants under NPK+VC were higher than other experimental plants. Total Flavonoid Content (TFC) in second-year plants under the combination of NPK was greater than other plants. N content in first year plants treated with NPK fertilizer / combination of NPK and VC was higher compared to other experimental plants. The highest $\mathrm{P}$ content was observed in the NPK application in first year. Gas Chromatography-Mass Spectrometry (GC/MS) analyses revealed that the main constitutes of $S$. macrantha EO were $p$ Cymene (16.30-34.64\%), $\gamma$-terpinene (15.46-33.6\%), and Thymol (14.82-43.09\%), which had different responses to sampling time and fertilizer treatments.
\end{abstract}

Correspondence: Hamid Mozafari, Department of Agronomy, Shahr-eQods Branch, Islamic Azad University, Tehran, Iran

E-mail: hamidmozafari1398@gmail.com

Key words: Essential oil; Thymol; Total phenol content; Nutrients uptake.

Conflict of Interests: The Authors declare no potential conflict of interests.

Received for publication: 9 August 2019.

Accepted for publication: 28 November 2019.

${ }^{\circ}$ Copyright: the Author(s), 2020

Licensee PAGEPress, Italy

Journal of Biological Research 2020; 93:8477

doi:10.4081/jbr.2020.8477

This article is distributed under the terms of the Creative Commons Attribution Noncommercial License (by-nc 4.0) which permits any noncommercial use, distribution, and reproduction in any medium, provided the original author(s) and source are credited.

\section{Introduction}

The genus satureja, belonging to Lamiaceae family, natively grows in Africa, southern and southeastern Europe, the middle east, and central Asia. Iran has 13 satureja species, in which S. macrantha L., as the most ones, grows in north-west of the country. ${ }^{1,2}$ Phenols, flavonoids, anthocyanins, sterols, diterpenes, and triterpenes are the main phytochemical compounds of $S$. macrantha L. 2,3 Essential oil of most satureja species

such as $S$. macrantha L. is mainly known by thymol and Carvacrol. ${ }^{1-3}$

Fertilization is considered as the most principal factor in plant nutrition. ${ }^{4}$ The type, amount, and application method of fertilizer directly affect the availability of plant nutrients and indirectly influenced physiological and biochemical mechanisms in plant. ${ }^{4}$ Chemical fertilizers are extensively used to enhance crop yield, albeit their long-term application change soil $\mathrm{pH}$, decrease beneficial soil microflora, pollute water supplies, and disturb soil ecological systems. ${ }^{5,6}$ However, in recent years, demand for organic products has increased due to their healthy and environmental consideration especially for medicinal products. ${ }^{6}$ Furthermore, tendency to medicinal plants cultivation with the application of soil amendments such as manures, mycorrhiza, and vermicompost has been increased. ${ }^{5}$ These compounds contain nutrients for crop growth. They improve physico-chemical attributes of the soil and increase organic matter, cation exchange, water holding capacity, and ultimately upgrade the quantity and the quality of medicinal plants. ${ }^{6}$

Literature reviews showed that inorganic and organic fertilizers can improve the quality and quantity of medicinal plants. For example, we can report the useful effect of Arbuscular Mycorrhizal Fungi (AMF) on Satureja macrostema, ${ }^{7}$ Sesbania sesban, ${ }^{8}$ and Leptospermum scoparium, ${ }^{9}$ the functional impact of vermicompost on Amaranthus retroflexus L., ${ }^{10}$ Drimiopsis maculata,${ }^{11}$ and the helpful reaction of NPK on Cucurbita pepo L. ${ }^{12}$ Totally, they demonstrated that the application of proper portion for different fertilizers, separately or in combination, can help the producers to reach the optimum products of medicinal plants.

To the best of our knowledge, there is no report on the combination of these soil amendments on phytochemical properties and leaf nutrients of $S$. macrantha L. Therefore, the aims of present study were i) to assess the effects of NPK, vermicompost, thiobacillus, sulfur, and G. mosseae, on plant nutrients, ii) to evaluate their effects on phenol, flavonoid and antioxidant capacity, and iii) to discover their effects on essential oil content and composition of $S$. macrantha $L$. 


\section{Materials and Methods}

\section{Experimental site}

This work was accomplished at the experimental farm in Alborz Research Station, Research institute of Forests and

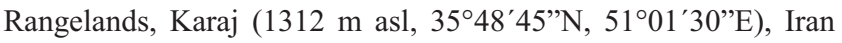
during 2017-2018. The soil features of the experimental site consisted of silt, lightly acidic ( $\mathrm{pH} 6.4$ ), high organic carbon (1.06\%), and presented a low availability of $\mathrm{N}\left(151.5 \mathrm{~kg} \mathrm{ha}^{-1}\right), \mathrm{P}(15.2 \mathrm{~kg}$ $\left.\mathrm{ha}^{-1}\right)$, and $\mathrm{K}\left(485.2 \mathrm{~kg} \mathrm{ha}^{-1}\right)$. During the study period mean maximum temperature fluctuated from $17.3^{\circ} \mathrm{C}$ to $28.2^{\circ} \mathrm{C}$; whereas; mean minimum temperature varied from $2.6^{\circ} \mathrm{C}$ to $15.4^{\circ} \mathrm{C}$. The highest precipitation occurred in March (43.2 mm) and April (39.1 $\mathrm{mm}$ ) (Figure 1).

\section{Fertilizers and soil amendments used}

For most types of soils, the manufacturer's suggested rate of $\mathrm{N}$ is considered at a rate of $50 \mathrm{~kg} \mathrm{~N}^{-1}$ applying ammonium nitrate (33\%); P was used at a rate of $25 \mathrm{~kg} \mathrm{P} \mathrm{ha}^{-1}$ using calcium super phosphate $(16 \%)$; and potassium sulphate $\left(48 \% \mathrm{~K}_{2} \mathrm{O}\right)$ was used for $\mathrm{K}$ at a rate of $25 \mathrm{~kg} \mathrm{~K} \mathrm{ha}^{-1}$. G. mosseae as a species of AMF was applied in rhizosphere. The mycorrhizal inocula (originally isolated by the endemic AMF group of a maize farm), a combination of sterile sand, hyphae and spores of AMF (20 spores/g inoculum) and colonized fragments of root, were provided by Research Institutes of Forest and Rangelands (RIFR), Iran. To produce Vermicompost (VC), adult epigeic species of clitellate earthworms, Eudrilius eugineae, composted a combine of distillation waste (plant-spent de-oiled herb) of aromatic grasses in a VC unit during three months. This VC combination was used as the organic fertilizer in our experiment. The VC included $1.07 \% \mathrm{~N}, 0.62 \% \mathrm{P}$ and $0.73 \% \mathrm{~K}$.

\section{Experimental details}

The experiment consisted of nine treatments viz., NPK (50:25:25 $\left.\mathrm{kg} \mathrm{ha}^{-1}\right)$, VC (5 $\left.\mathrm{t} \mathrm{ha}^{-1}\right), \mathrm{NPK}+\mathrm{VC}$, Thiobacillus (T), $\mathrm{T}+\mathrm{VC}, \mathrm{T}+$ sulfur $(\mathrm{S})\left(250 \mathrm{~kg} \mathrm{ha}^{-1}\right), \mathrm{T}+\mathrm{S} 500 \mathrm{~kg} \mathrm{ha}^{-1}$, G. mosseae, and control (untreated plants). The experiment was fulfilled in randomized complete block design (RCBD) with three replications. Seeds of $S$. macrantha L. were sown in the culture trays prepared with a cocopeat perlite mixture (1:1 volume). Two-month seedlings were transplanted in the farm at a spacing of $50 \mathrm{~cm}$ (row to row) $\times 50 \mathrm{~cm}$ (plant to plant) during march 2017 and 2018 . Inorganic fertilizer $(\mathrm{N}, \mathrm{P}$, and $\mathrm{K})$ were applied utilizing urea $(\mathrm{N}$ $50 \%$ ). Irrigation was fulfilled weekly during non-rainy season.

\section{Determination of $\mathbf{N}, P$ and $K$ content}

Dried powder $(100 \mathrm{mg})$ of leaves was precisely transferred to a digestion tube and $2 \mathrm{~cm}^{3}$ of AR grade concentrated sulphuric acid was added. It was heated on a temperature controlled assembly at $80{ }^{\circ} \mathrm{C}$ for $2 \mathrm{~h}$. On heating, the contents of the tube turned black. It was cooled at room temperature for $15 \mathrm{~min}$ and then $0.5 \mathrm{~cm}^{3}$ of $\mathrm{H} 2 \mathrm{O} 2(30 \%)$ was added drop by drop. The addition of $\mathrm{H}_{2} \mathrm{O}_{2}$ followed by gentle heating was repeated until the contents of the tube being changed colorless. The aliquot (peroxide-digested material) was used to estimate percentage content of N, P and $\mathrm{K}$ in the shoot on dry weight basis.

\section{Estimation of $N$ content}

Dried powder $(0.2 \mathrm{~g})$ of aerial parts was used based on digestion method. After preparing the digested solution, we determined the concentrations of $\mathrm{N}$ content by Kjeldahl. ${ }^{13}$ For this purpose, 0.2 $\mathrm{g}$ of dried plant was combined with $20 \mathrm{ml}$ of sulfuric acid and a Kjeldahl tablet. The mixture was then placed in a digestive tube in the oven at $400{ }^{\circ} \mathrm{C}$ until the sample color would change to a light green. The resulting solutions were cooled at room temperature and diluted by adding sulfuric acid $(0.01 \mathrm{~N})$ until the color would turn to red. The volume of acid consumed was recorded and $\mathrm{N}$ content calculated as follows: $\mathrm{N} \%=\mathrm{A} * \mathrm{~N} * 1.4 / \mathrm{W}$; where $\mathrm{N}$ is normality of the used acid, A is the volume of used acid, and $\mathrm{W}$ is weight of leaf sample.

\section{Estimation of $P$ content}

For P measurement, a $5 \mathrm{~cm}^{3}$ aliquot was taken in a $10 \mathrm{~cm}^{3}$ graduated test tube. To it, $1 \mathrm{~cm}^{3}$ molybdic acid (2.5\%) was added carefully, followed by addition of $0.4 \mathrm{~cm}^{3}$ of 1-amino-2-naphthol-4sulphonic acid. When the color turned blue, the volume was made up to $10 \mathrm{~cm}^{3}$ with double distilled water (DDW). The O.D. of the solution was recorded at $620 \mathrm{~nm}$ using the spectrophotometer. The $\mathrm{P}$ content was estimated using a standard graph prepared by graded dilutions of monopotassium phosphate. ${ }^{14}$

\section{Estimation of $K$ content}

$\mathrm{K}$ content in the leaves was determined flame photometrically in the peroxide-digested material with the help of emission spectra using specific filters. In the flame-photometer, the solution (peroxide digested material) was discharged through an atomizer in the form of a fine mist into a chamber, where it was drawn into a flame. Combustion of the elements produced the light of a particular wavelength [ $(\lambda \max$ for $K=767 \mathrm{~nm}$ (violet) $]$. The light produced was conducted through the appropriate filters to impinge upon a photoelectric cell that activated a galvanometer, resulting in the digital reading of the respective samples. ${ }^{15}$

\section{Essential oil extraction}

In order to identify the EO content, during peak flowering season, $100 \mathrm{~g}$ of dried aerial parts from each treatment were hydrodistilled in the Clevenger type apparatus for $3 \mathrm{hr}$. The EO content was measured and reported as $\mathrm{v} / \mathrm{w}$ percentage. The EO yield $\left(\mathrm{kg} \mathrm{ha}^{-1}\right)$ was measured with multiplying the EO content with the plant yield of the experimental treatments. Anhydrous sodium sulfate was used to dry EO samples, and finally the samples were stored at $4^{\circ} \mathrm{C}$ to further analysis of Gas Chromatography (GC) and Gas Chromatography-Mass Spectrometry (GC-MS).

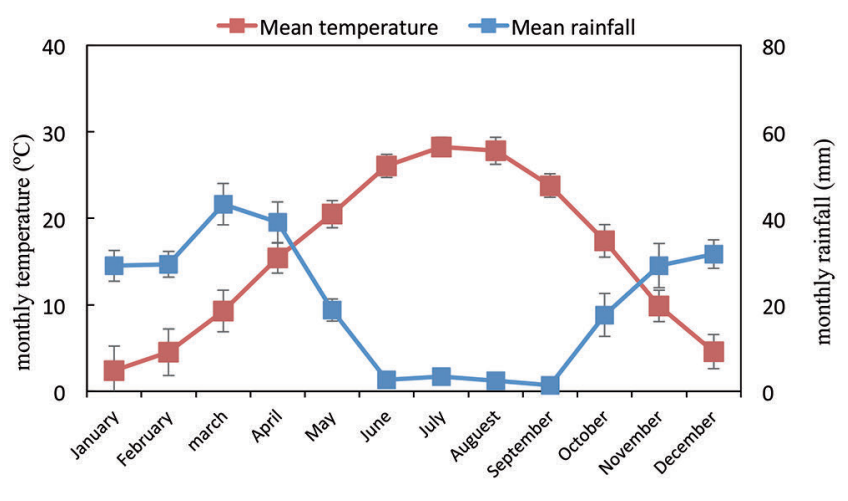

Figure 1. Mean temperature and rainfall in the case study. 


\section{Gas Chromatography (GC) analysis}

Thermo-UFM ultrafast gas chromatograph equipment with a ph-5 fused silica column $(10 \mathrm{~m}$ length $\times 0.1 \mathrm{~mm}$ id., film thickness $0.4 \mu \mathrm{m})$ was used to anlyze EOs. Oven temperature was maintained at $60^{\circ} \mathrm{C}$ for $5 \mathrm{~min}$ and then programmed to $285^{\circ} \mathrm{C}$ at a rate of $5^{\circ} \mathrm{C} \mathrm{min}-1$; Flame Ionization Detector (FID) and injector temperature were $290^{\circ} \mathrm{C}$ and $280^{\circ} \mathrm{C}$, respectively; helium was applied as carrier gas with an inlet pressure of $0.5 \mathrm{~kg} \mathrm{~cm}^{-2}$.

\section{Gas Chromatography—Mass Spectrometry (GC-MS)}

GC-MS analyses were accomplished by Varian 3400 GC-MS system equipment with AOC-5000 auto injector and DB-5 fused silica capillary column $(30 \mathrm{~m} \times 0.25 \mathrm{~mm}$ i.d.; film thicknesses $0.25 \mu \mathrm{m}$ ). Temperature was programmed from $60^{\circ} \mathrm{C}$ to $250^{\circ} \mathrm{C}$ with $3{ }^{\circ} \mathrm{C} \mathrm{min}-1$; Injector and interface temperature were $260{ }^{\circ} \mathrm{C}$ and $270^{\circ} \mathrm{C}$, respectively; acquisition mass range of 40-340 amu; ionization voltage of $70 \mathrm{eV}$; the carrier gas was helium at a velocity of $45 \mathrm{~cm} \mathrm{sec}^{-1}$.

\section{Component identification}

Homologous series of n-alkanes $\left(\mathrm{C}_{7}-\mathrm{C}_{25}\right)$ determined the retention index for all volatile constituents. According to Adams, the components of oil were identified by matching their Retention Indices (RI) and mass spectra. EO components were identified by GC/MS spectroscopy.

\section{Determination of Total Phenolic Content (TPC)}

Folin-Ciocalteu reagent was selected to measure TPC spectrophotometrically. ${ }^{16} 100 \mu \mathrm{l}$ of the $\mathrm{MeOH}$ solution of the precisely measured weight of investigated plant $1-10(2.54,2.58,2.25,4.03$, $4.80,2.13,4.62,1.47,1.58,15.05 \mathrm{mg} / \mathrm{mL}$ respectively) were mixed with $0.75 \mathrm{~mL}$ of Folin-Ciocalteu reagent and allowed to stay at $22^{\circ} \mathrm{C}$ for $5 \mathrm{~min}$. The mixture was supplied with $0.75 \mathrm{ml}$ of $\mathrm{NaHCO}_{3}$. Absorbance was measured at $725 \mathrm{~nm}$ by UV-vis spectrophotometer (Varian Cary 50) after $90 \mathrm{~min}$ at $22{ }^{\circ} \mathrm{C}$. Standard curve was calibrated by Gallic acid $(0-100 \mathrm{mg} / ; \mathrm{r}>0.99)$. The results were represented as $\mathrm{mg}$ Gallic acid /g Dry weight.

\section{Determination of Total Flavonoid Content (TFC)}

The method with aluminum chloride was applied to measure the total flavonoid content. ${ }^{17}$ Briefly, the mixture containing 0.5 $\mathrm{mL}$ of sample and $300 \mu \mathrm{L}$ of $\mathrm{NaNO}_{2}(1: 20 \mathrm{w} / \mathrm{v})$ was vortexed for $10 \mathrm{~s}$ and left to stand at $24^{\circ} \mathrm{C}$ for $5 \mathrm{~min}$. After that, the reaction mixture was changed by $300 \mu \mathrm{L}$ of $\mathrm{AlCl}_{3}(1: 10 \mathrm{w} / \mathrm{v}), 2 \mathrm{~mL}$ of $\mathrm{NaOH}(1 \mathrm{M})$ and $1.9 \mathrm{~mL}$ of distilled water, and then vortexed for $10 \mathrm{~s}$. The absorbance was determined at $510 \mathrm{~nm}$. Quercetin concentrations ranging from 0 to $1200 \mu \mathrm{g} / \mathrm{mL}$ were prepared and linear fit was used for calibration of the standard curve.

\section{Radical scavenging activity}

Free radical scavenging activities of the extracts was measured using a DPPH radical described by Brand-Williams et al:: $0.1 \mathrm{ml}$ of the extract solution was mixed with $1.0 \mathrm{ml}$ of DPPH solution and $4 \mathrm{ml}$ of methanol. ${ }^{18}$ The absorbance wavelength was $517 \mathrm{~nm}$ performed by UV-vis spectrophotometer (Varian Cary 50). The scavenging effect was determined as follow:

DPPH scavenging $\%=$

[1/(A $517 \mathrm{~nm}$, sample - A $517 \mathrm{~nm}$, control $)] \times 100$. (1)

(Eq. 1)

\section{Statistical analysis}

The data $(n=3)$ were subjected to one-way analysis of variance (ANOVA) and using the SAS software package for Windows (SAS, version 9.3, SAS Institute, Cary, NC). Duncan's multiple range tests showed the comparison of mean values. The data were statistically investigated at 5\% probability level.

\section{Results}

\section{Macronutrients (NPK)}

The interaction of fertilizer and sampling time was significant on NPK $(P \leq 0.05)$. N in first year plants treated with NPK fertilizer / combination of NPK and VC was higher than that in other plants (Figure 2). The highest $\mathrm{P}$ content was observed in the NPK application in first year as $0.28 \pm 0.029 \%$. In contrast, the lowest $\mathrm{P}$ was in the untreated plants in both first and second year (Figure 3). K in plants with application of NPK fertilizer in first

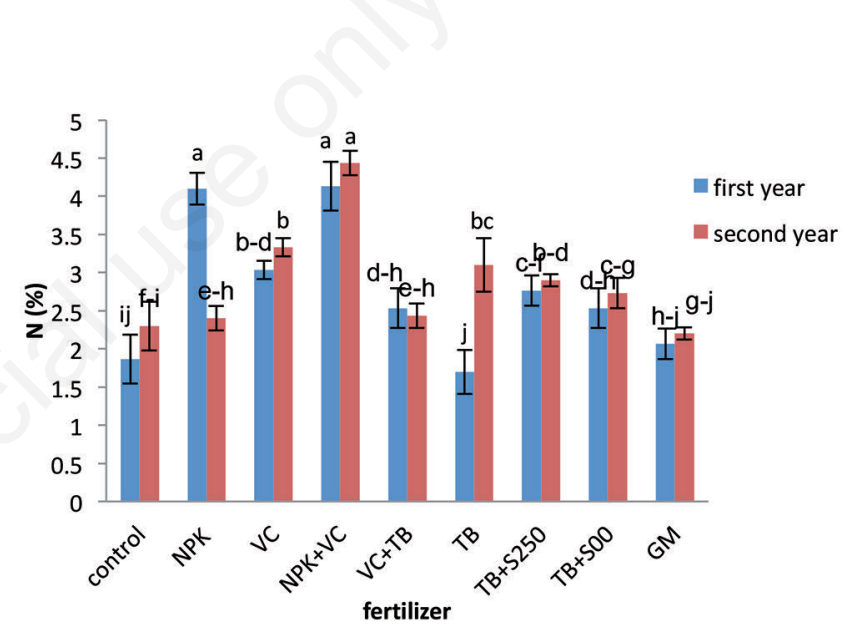

Figure 2. Nitrogen $(\mathrm{N})$ content under fertilizer and time. Means followed by the same letter are not significantly different $(P<0.05)$ as determined by Duncan's multiple range test.

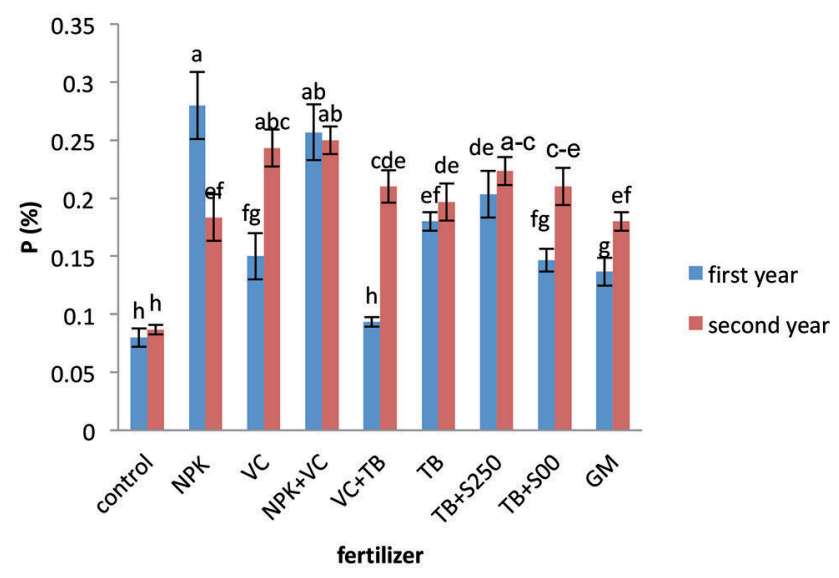

Figure 3. Phosphorous (P) content under fertilizer and time. Means followed by the same letter are not significantly different $(P<0.05)$ as determined by Duncan's multiple range test. 
and second year, as $4.4 \pm .16 \%$ and $4.1 \pm .15 \%$ respectively, was greater than other treatments (Figure 4).

\section{Essential Oil (EO) content and yield}

Both EO content and yield were affected by fertilizer and time $(P \leq 0.05)$. The highest EO content $(2.025 \pm 0.1 \%)$ and EOY $(55.04 \pm 3.7 \mathrm{~kg} / \mathrm{ha})$ was respectively observed in plants under the combination of VC and NPK (Table 1). In contrast, the lowest EO content and yield was recorded in untreated plants $(0.72 \pm 0.06 \%$, $7.26 \pm 0.9 \mathrm{~kg} / \mathrm{ha})$, and plants inoculated with $G$. mosseae $(0.81 \pm 0.06 \%, 10.71 \pm 1.6 \mathrm{~kg} / \mathrm{ha})$ (Table 1). Both EO content and yield in second year $(1.37 \pm 0.4 \%, 27.4 \pm 7 \mathrm{~kg} / \mathrm{ha})$ was greater than those in first year $(1.09 \pm 0.4 \%, 23.2 \pm 8 \mathrm{~kg} / \mathrm{ha}$ ) (Table 2).

Total Phenolic Content (TPC), Total Flavonoid Content

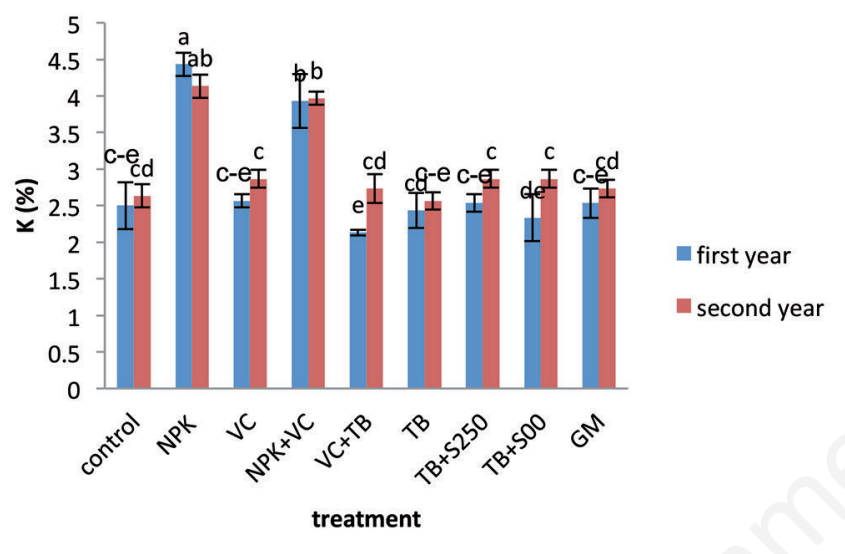

Figure 4. Potassium (K) content under fertilizer and time. Means followed by the same letter are not significantly different $(P<0.05)$ as determined by Duncan's multiple range test.

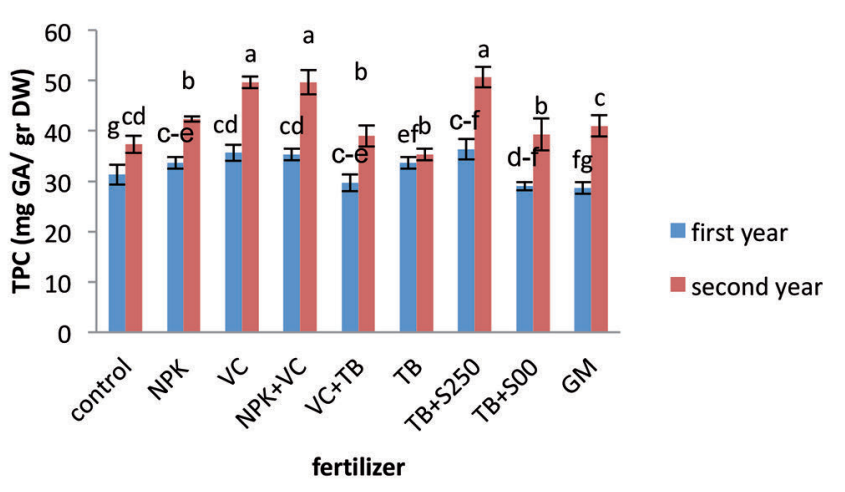

Figure 5. Total phenolic content (TFC) under fertilizer and time. Means followed by the same letter are not significantly different $(P<0.05)$ as determined by Duncan's multiple range test.

\section{(TFC), and DPPH-scavenging activity}

The TPC, TFC, and DPPH-scavenging activity were influenced by the interaction of fertilizer and time $(P \leq 0.05)$. TPC in first-year plants treated with $\mathrm{VC}$, and second-year plants treated with NPK+VC, as well as second-year plants with TB + sulfur 500 were higher than other plants (Figure 5). TFC in second-year plants treated with combination of NPK and VC $(15.2 \pm 1.7 \mathrm{mg}$ quercetin/gr DW) and second-year plants with VC (14. $8 \pm 0.5 \mathrm{mg}$ quercetin/gr DW) were greater than other experimental plants (Figure 6). DPPH-scavenging activity in second-year plants under $\mathrm{TB}+\mathrm{S} 500(86.33 \pm 3 \%)$ was higher compared with other plants (Figure 7).

\section{Essential oil composition}

The GC/MS analysis showed 24 compounds of $S$. macrantha L. EO, which most of these components were monoterpene (Tables

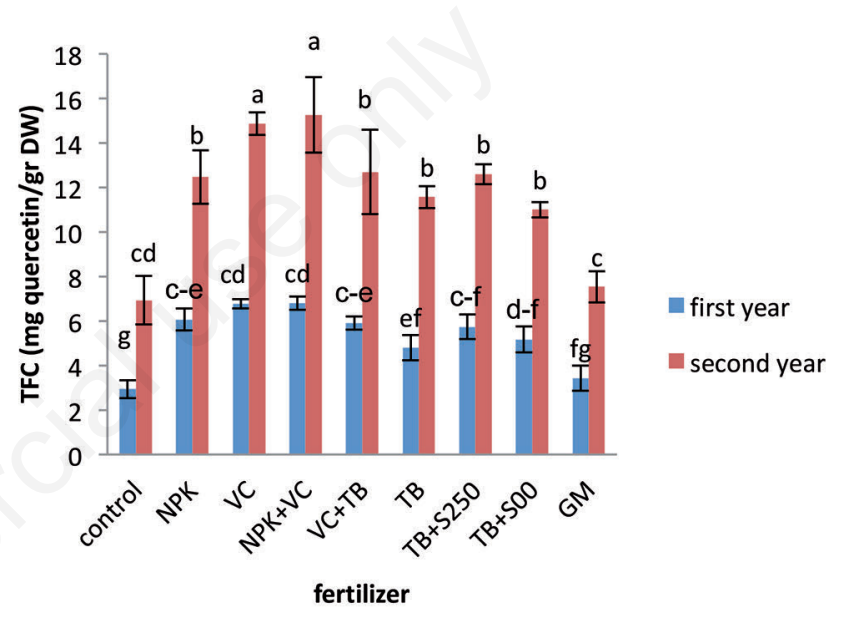

Figure 6. Total flavonoid content (TFC) under fertilizer and time. Means followed by the same letter are not significantly different $(P<0.05)$ as determined by Duncan's multiple range test. 
3 and 4). $p$-Cymene, $\gamma$-terpinene, and Thymol were the main constitutes of $S$. macrantha EO (Tables 3 and 4). $p$-Cymene was different during two year and fertilizer treatments. This in plants treated with the combination of VC and NPK (30.08\%) was higher than other treatments in first year. In contrast, its high content was changed to the combination of TB and S250 (29.95\%) in second year. In first year, $\gamma$-terpinene in EOs of plants under the combination of VC and NPK was higher compared to other treatments. However, its maximum content in second year was observed in plants inoculated with $G$. Mosseae (30\%). Thymol- acetate was fluctuated from the untreated plants $(24.91 \%)$ to the combination of TB and S500 (43.09\%) in first year. This trend in second year varied from control $(14.82 \%)$ to application of NPK $(37.57 \%)$.

\section{Discussion}

NPK fertilizer in combination with VC increased the N, K, and $\mathrm{P}$ contents. A $92 \%$ increase of $\mathrm{N}$ content in aerial parts was observed in second-year plants under combination of NPK fertilizer and VC compared to untreated plants. In addition, we found a $77 \%$ increase of $\mathrm{K}$ content in first-year plants under NPK fertilizer relative to untreated plants. This increase in first year for $\mathrm{P}$ content was recorded 2.5 fold in NPK-treated plants compared to untreated plants. NPK fertilizer increase the availability in rhizosphere and
Table 1. Essential oil (EO) content and yield of $S$. macrantha L. under different fertilizer treatments.

\begin{tabular}{lcc} 
Treatment & EO content (\%) & EO yield (kg/ha) \\
Control & $0.72 \pm 0.06 \mathrm{e}$ & $7.26 \pm 0.9 \mathrm{e}$ \\
NPK & $1.33 \pm 0.13 \mathrm{c}$ & $30.78 \pm 2.2 \mathrm{c}$ \\
\hline Vermicompost & $1.43 \pm 0.1 \mathrm{bc}$ & $31.89 \pm 2.8 \mathrm{c}$ \\
NPK + Vermicompost & $2.025 \pm 0.1 \mathrm{a}$ & $55.04 \pm 3.7 \mathrm{a}$ \\
\hline Vermicompost + & & \\
Thiobacillus & $1.52 \pm 0.53 \mathrm{~b}$ & $37.31 \pm 2.3 \mathrm{~b}$ \\
Thiobacillus & $1.01 \pm 0.07 \mathrm{~d}$ & $16.06 \pm 4 \mathrm{~d}$ \\
Thiobacillus + S250 & $1.09 \pm 0.11 \mathrm{~d}$ & $18.61 \pm 3.2 \mathrm{~d}$ \\
Thiobacillus + S500 & $1.165 \pm 0.1 \mathrm{~d}$ & $20.19 \pm 4.1 \mathrm{~d}$ \\
G. mosseae & $0.81 \pm 0.06 \mathrm{e}$ & $10.71 \pm 1.6 \mathrm{e}$
\end{tabular}

Table 2. Essential oil (EO) content and yield of $S$. macrantha $\mathrm{L}$. during 2017 and 2018.

\begin{tabular}{lcc} 
Time & EO content (\%) & EO yield (kg/ha) \\
2017 & $1.09 \pm 0.4 \mathrm{~b}$ & $23.2 \pm 8 \mathrm{~b}$ \\
2018 & $1.37 \pm 0.4 \mathrm{a}$ & $27.4 \pm 7 \mathrm{a}$ \\
\hline
\end{tabular}

Table 3. Percentage of essential oil (EO) composition in S. macrantha L. under different fertilizer treatments in 2017.

\begin{tabular}{|c|c|c|c|c|c|c|c|c|c|c|c|}
\hline No & Compound & RI & $\begin{array}{c}\text { Control } \\
(\%)\end{array}$ & $\begin{array}{l}\text { NPK } \\
(\%)\end{array}$ & $\begin{array}{l}\mathrm{VC} \\
(\%)\end{array}$ & $\begin{array}{c}\mathrm{NPK}+\mathrm{VC} \\
(\%)\end{array}$ & $\begin{array}{c}\mathrm{TB}+\mathrm{VC} \\
(\%)\end{array}$ & $\begin{array}{l}\text { TB } \\
(\%)\end{array}$ & $\begin{array}{c}\mathrm{TB}+\mathrm{S} 250 \\
(\%)\end{array}$ & $\begin{array}{c}\mathrm{TB}+\mathrm{S} 500 \\
(\%)\end{array}$ & $\begin{array}{l}\text { GM } \\
(\%)\end{array}$ \\
\hline 1 & $\alpha$-thujene & 934.61 & 1.53 & 0.85 & 2.22 & 1.17 & 0.86 & 1.23 & 1.28 & 0.92 & 0.59 \\
\hline 2 & $\alpha$-pinene & 946.09 & 2.17 & 0.7 & 0.75 & 1.5 & 1.07 & 1.9 & 1.95 & 0.75 & 0.7 \\
\hline 3 & Camphene & 962.66 & 0.18 & 0.11 & 0.21 & 0.16 & 0.1 & 0.14 & 0.19 & 0.12 & 1.87 \\
\hline 4 & Sabinene & 976.79 & 2.49 & 1.89 & 1.01 & 2.46 & 2.2 & 2.1 & 2.2 & 1.73 & 0.52 \\
\hline 5 & $\beta$-pinene & 1007.94 & 1.29 & 0.41 & 0.54 & 0.97 & 0.77 & 1.28 & 1.17 & 0.41 & 0.13 \\
\hline 6 & 3-octanone & 1033.65 & 0.18 & 0.17 & 0.18 & 0.18 & 0.14 & 0.17 & 0.21 & 0.17 & 2.03 \\
\hline 7 & Myrcene & 1043.62 & 2.67 & 2.65 & 2.35 & 2.53 & 2.43 & 2.59 & 3.21 & 2.55 & 1.88 \\
\hline 8 & $\alpha$-terpinene & 1046.08 & 2.32 & 0.33 & 0.55 & 1.18 & 1.55 & 0.98 & 0.95 & 0.15 & 2.04 \\
\hline 9 & $p$-cymene & 1053.41 & 27.54 & 17.47 & 25.4 & 30.08 & 22.72 & 26.53 & 16.4 & 16.3 & 17.74 \\
\hline 10 & $\beta$-phellandrene & 1055.84 & 0.27 & 0.23 & 0.26 & 1.67 & 1.94 & 1.37 & 0.27 & 0.25 & 0.11 \\
\hline 11 & (Z)- $\beta$-ocimene & 1060.65 & 2.62 & 0.38 & 1.11 & 0.19 & 0.14 & 0.18 & 1.19 & 0.21 & 0.13 \\
\hline 12 & (E)- $\beta$-ocimene & 1063.04 & 0.12 & 0.12 & 0.1 & 0.24 & 0.25 & 0.24 & 0.17 & 0.12 & 0.29 \\
\hline 13 & $\gamma$-terpinene & 1084.13 & 28.2 & 28.93 & 24.4 & 30.39 & 27.51 & 29.92 & 33.6 & 28.23 & 25.69 \\
\hline 14 & cis-sabinene hydrata & 1100 & 0.26 & 0.23 & 0.18 & 0.16 & 0.15 & 0.13 & 0.18 & 0.25 & 0.23 \\
\hline 15 & Terpinene-4-ol & 1219.85 & 0.3 & 0.15 & 0.52 & 0.13 & 0.18 & 0.2 & 0.16 & 0.16 & 0.19 \\
\hline 16 & Carvacrol & 1322.63 & 0.2 & 0.21 & 0.28 & 0.54 & 0.15 & 0.14 & 0.95 & 0.17 & 0.96 \\
\hline 17 & Thymol-acetate & 1330.04 & 24.91 & 40.48 & 34.23 & 22.06 & 34.13 & 27.25 & 31.86 & 43.09 & 39.56 \\
\hline 18 & $(E)-\beta$ caryophyllene & 1476.54 & 0.43 & 0.51 & 0.16 & 1.37 & 1.2 & 0.2 & 1.41 & 0.62 & 1.63 \\
\hline 19 & Aromadendrene & 1497.09 & 0.12 & 0.28 & 0.55 & 0.19 & 0.13 & 1.08 & 0.2 & 0.47 & 0.21 \\
\hline 20 & Germacrene d & 1520.15 & 0.74 & 1.28 & 0.32 & 0.16 & 0.12 & 0.14 & 0.18 & 1.1 & 0.18 \\
\hline 21 & Bicyclogermacrene & 1534.32 & 0.56 & 0.22 & 0.62 & 0.97 & 0.73 & 0.14 & 0.91 & 0.14 & 1.01 \\
\hline 22 & $\beta$-bisabolene & 1542.75 & 0.22 & 0.14 & 0.17 & 0.2 & 0.17 & 0.77 & 0.27 & 0.12 & 0.25 \\
\hline 23 & e-cadinene & 1548.33 & 0.4 & 0.72 & 0.29 & 0.42 & 0.38 & 0.16 & 0.49 & 0.57 & 0.41 \\
\hline \multirow[t]{2}{*}{24} & Spathulenol & 1556.66 & 0.19 & 0.26 & 0.78 & 0.16 & 0.1 & 0.32 & 0.18 & 0.18 & 0.18 \\
\hline & Total (\%) & & 99.91 & 98.72 & 97.18 & 99.08 & 99.12 & 99.16 & 99.58 & 98.78 & 98.53 \\
\hline
\end{tabular}

$\mathrm{VC}$, Vermicomost; TB, thiobacillus; S, sulfur; GM, glomus mosseae. 
plant can uptake these essential elements properly. VC can increase the availability of essential elements for plant particularly the amounts of $\mathrm{N}$ and $\mathrm{P}$. The increase of $\mathrm{N}, \mathrm{P}$, and $\mathrm{K}$ uptake by leaves of plants have been reported under $\mathrm{VC},{ }^{19} \mathrm{NPK},{ }^{20}$ and combination of $\mathrm{VC}$ and NPK. ${ }^{21}$

Inorganic fertilizer, VC, and combination of $\mathrm{TB}$ and sulfur improved the antioxidant activity of $S$. macrantha. Phytochemical properties of humid substance in VC improve the antioxidant capacity of plants. ${ }^{22}$ Phenolic acids are an important group of secondary metabolites, which found in medicinal plants, and they show strong antioxidant activities due to their carboxyl groups and hydroxyl. ${ }^{23}$ Hydroxycinnamic acids and hydroxybenzoic acids are two main groups of phenolic acids. Flavonoids via demolishment and detoxification of free radicals have strong impacts on cell biology. ${ }^{23}$ In this regard, VC can play an important role in use of organic manufacturing systems to improve the flavonoids biosynthesis in plants. An increase of phenol and flavonoid content in Pumpkin under NPK fertilizer were recorded by Oloyede et al.. ${ }^{12}$ Some reports have shown the positive influence of VC in increasing the synthesis of flavonoids in plants. The amounts of phenolic compounds are strongly correlated with antioxidant power of the plant. ${ }^{24}$ The application of humic substances enhances the plant ability to vanish free radicals by increasing phenolic compounds. ${ }^{22}$ This elucidates the role of these fertilizers in the compounds biosynthesis to motivate high production of shikimic acid, causing more production of phenolic compounds such as flavonoids. ${ }^{4}$ How to use the elements is economically and ecologically equals to the amounts of elements. ${ }^{4}$ To note a few, C: $\mathrm{N}$ ratio in plants encourages the production of carbon-containing metabolites such as phenolic acids. The $\mathrm{C}: \mathrm{N}$ ratio in organic fertilizers can induce stronger antioxidant activity in plants by increasing their phenolic compounds. VC due to the presence of humic substances has a significant role in plant health and viability. These substances increase the plant resistance to stressful conditions via enhancing the biosynthesis of phenolics. ${ }^{25}$ Outbreak of many chronic diseases such as cardiovascular disease, cancer, and liver disorders can be prevented and curved by plant antioxidants. Therefore, the boost of antioxidant capacity in plants is a principal strategy in preventing human maladies. ${ }^{26}$ Soil calcium carbonate determines the application of sulfur and TB for plants. The previous works have shown different responses of plants to applications of sulfur and $\mathrm{TB}$ on soil. ${ }^{27,28} \mathrm{~TB}$ increased the oxidation of sulfur, which cusses the reduction of soil $\mathrm{pH}$. Therefore, nutrients availability in soil increased, which results in augmentation of plant growth. ${ }^{28}$

EO quality and quantity was influenced by soil amendments and time. Similar to our work, ${ }^{3}$ reported that the main EO components of $S$. macrantha L. were $p$-Cymene, $\gamma$-terpinene, and Thymol. EO yield increase by application of soil amendments particularly the integrated NPK and VC. The similar trends were observed during previous works, where significantly greater EO

Table 4. Percentage of essential oil (EO) composition in S. macrantha L. under different fertilizer treatments in 2018.

\begin{tabular}{|c|c|c|c|c|c|c|c|c|c|c|c|}
\hline No & Compound & RI & $\begin{array}{c}\text { Control } \\
(\%)\end{array}$ & $\begin{array}{l}\text { NPK } \\
(\%)\end{array}$ & $\begin{array}{l}\text { VC } \\
(\%)\end{array}$ & $\begin{array}{c}\mathrm{NPK}+\mathrm{VC} \\
(\%)\end{array}$ & $\begin{array}{c}\mathrm{TB}+\mathrm{VC} \\
(\%)\end{array}$ & $\begin{array}{l}\text { TB } \\
(\%)\end{array}$ & $\begin{array}{c}\mathrm{TB}+\mathrm{S} 250 \\
(\%)\end{array}$ & $\begin{array}{c}\mathrm{TB}+\mathrm{S} 500 \\
(\%)\end{array}$ & $\begin{array}{l}\text { GM } \\
(\%)\end{array}$ \\
\hline 1 & $\alpha$-thujene & 934.61 & 1.88 & 1.59 & 1.35 & 1.28 & 1.29 & 1.58 & 1.92 & 1.35 & 1.63 \\
\hline 2 & $\alpha$-pinene & 946.09 & 1.94 & 1.72 & 0.76 & 2.01 & 2.05 & 3.98 & 2.72 & 2.44 & 1.58 \\
\hline 3 & Camphene & 962.66 & 1.04 & 0.2 & 0.24 & 0.24 & 0.16 & 0.21 & 0.28 & 0.23 & 0.18 \\
\hline 4 & Sabinene & 976.79 & 2.12 & 1.17 & 1.94 & 1.93 & 2.17 & 0.33 & 2.39 & 2.13 & 2.12 \\
\hline 5 & $\beta$-pinene & 1007.94 & 2.16 & 0.94 & 0.27 & 1.31 & 1.29 & 2.28 & 1.47 & 1.46 & 0.79 \\
\hline 6 & 3-octanone & 1033.65 & 2.25 & 0.19 & 0.18 & 0.16 & 0.16 & 2.56 & 0.16 & 0.16 & 0.19 \\
\hline 7 & Myrcene & 1043.62 & 1.29 & 2.63 & 2.35 & 1.24 & 2.31 & 0.23 & 2.46 & 2.26 & 2.85 \\
\hline 8 & $\alpha$-terpinene & 1046.08 & 2.31 & 0.8 & 0.97 & 1.15 & 0.57 & 1.96 & 1.25 & 1.09 & 0.67 \\
\hline 9 & p-cymene & 1053.41 & 16.34 & 20.74 & 26.63 & 26.42 & 24.63 & 33.64 & 29.95 & 23.06 & 22.66 \\
\hline 10 & $\beta$-phellandrene & 1055.84 & 2.35 & 0.27 & 0.26 & 0.23 & 0.24 & 3.03 & 0.36 & 0.26 & 0.29 \\
\hline 11 & $(Z)$ - $\beta$-ocimene & 1060.65 & 2.36 & 0.97 & 1.11 & 1.44 & 0.68 & 3.77 & 1.49 & 1.42 & 0.88 \\
\hline 12 & $(E)$ - $\beta$-ocimene & 1063.04 & 2.38 & 0.16 & 0.1 & 0.09 & 0.2 & 0.16 & 0.19 & 0.17 & 0.18 \\
\hline 13 & $\gamma$-terpinene & 1084.13 & 15.46 & 27.15 & 25.57 & 26.65 & 24.58 & 23.69 & 26.06 & 23.08 & 30 \\
\hline 14 & cis-sabinene hydrata & 1100 & 2.54 & 0.27 & 0.18 & 0.23 & 0.15 & 0.22 & 0.25 & 0.25 & 0.2 \\
\hline 15 & Terpinene-4-ol & 1219.85 & 3.01 & 0.34 & 0.52 & 0.44 & 0.47 & 0.44 & 0.35 & 0.13 & 0.38 \\
\hline 16 & Carvacrol & 1322.63 & 3.13 & 0.22 & 0.27 & 0.28 & 0.35 & 0.36 & 0.21 & 0.47 & 0.28 \\
\hline 17 & Thymol- acetate & 1330.04 & 14.82 & 37.57 & 34.22 & 29.57 & 35.59 & 16.72 & 24.51 & 36.49 & 32.49 \\
\hline 18 & $(E)-\beta$ caryophyllene & 1476.54 & 3.91 & 0.17 & 0.16 & 0.55 & 0.23 & 0.54 & 0.22 & 0.49 & 0.74 \\
\hline 19 & Aromadendrene & 1497.09 & 4.11 & 0.73 & 0.54 & 1.29 & 0.77 & 0.69 & 0.75 & 0.32 & 0.64 \\
\hline 20 & Germacrene d & 1520.15 & 4.16 & 0.51 & 0.32 & 0.89 & 0.15 & 1.04 & 0.44 & 1.03 & 0.27 \\
\hline 21 & Bicyclogermacrene & 1534.32 & 4.45 & 0.4 & 0.62 & 0.36 & 0.61 & 0.28 & 0.37 & 0.71 & 0.66 \\
\hline 22 & $\beta$-bisabolene & 1542.75 & 4.48 & 0.28 & 0.18 & 0.67 & 0.32 & 0.94 & 0.22 & 0.58 & 0.3 \\
\hline 23 & e-cadinene & 1548.33 & - & - & 0.29 & 0.41 & 0.62 & 0.3 & - & 0.41 & - \\
\hline \multirow[t]{2}{*}{24} & Spathulenol & 1556.66 & - & & 0.81 & 0.26 & 0.31 & 1.03 & & & \\
\hline & Total (\%) & & 98.49 & 99.02 & 99.84 & 99.1 & 99.9 & 99.98 & 98.02 & 99.99 & 99.98 \\
\hline
\end{tabular}


yield observed in satureja plants supplied with VC, sulfur, AMF such as Glomus fasciculatum, G. intraradices and G. mosseae, and plant growth promoters like Pseudomonas fluorescens and Bacillus subtilis. ${ }^{10,29}$ The EO quality was changed by application of the soil amendments and time. For example, in the first year, a $10 \%$ increase of $p$-cymene amount was observed using the combination of NPK and VC in respect to untreated plants. However, this increase in second year was $61 \%$. The change of EO composition amount can be due to the physiology of plant, the biochemical pathways of producing the corresponded compounds, and the responses of plants to time and site. ${ }^{30}$

\section{Conclusions}

In the study, organic, Bio-organic and inorganic fertilizers improved plant nutrients, essential oil composition and antioxidant capacity of $S$. macrantha $\mathrm{L}$. We found the improvement of nutrients uptake, antioxidant potential, and $\mathrm{EO}$ properties under most soil amendments. However, the VC in combination with NPK fertilizer gave the best results for increasing the EO quality and quantity as well as the antioxidant capacity of this species. Hence, we can recommend the $5 \mathrm{t} \mathrm{ha}^{-1} \mathrm{VC}$ in combination with 50:25:25 $\mathrm{kg} \mathrm{ha}^{-1} \mathrm{NPK}$ for improving the quality and quantity of $S$. macrantha products.

\section{References}

1. Gohari AR, Hadjiakhoondi A, Sadat-Ebrahimi E, et al. Cytotoxic terpenoids from Satureja macrantha CA Mey. J Pharm Sci 2005;13:177-81.

2. Saharkhiz MJ, Zomorodian K, Taban A, et al. Chemical composition and antimicrobial Activities of three Satureja species against food-borne pathogens. J Essent Oil Bear Plant 2106;19:1984-92.

3. Sefidkon F, Jamzad, Z. Chemical composition of the essential oil of three Iranian Satureja species (S. mutica, S. macrantha and S. intermedia). Food chem 2005;91:1-4.

4. Naguib AEMM, El-Baz FK, Salama, ZA et al. Enhancement of phenolics, flavonoids and glucosinolates of Broccoli (Brassica olaracea, var. Italica) as antioxidants in response to organic and bio-organic fertilizers. J Saudi Soc Agr Sci 2012;11: 135-42.

5. Rostaei M, Fallah S, Lorigooini Z, et al. Crop productivity and chemical compositions of black cumin essential oil in sole crop and intercropped with soybean under contrasting fertilization. Ind Crop Prod 2018;125:622-9.

6. Bistgani ZE, Siadat SA, Bakhshandeh A, et al. Application of combined fertilizers improves biomass, essential oil yield, aroma profile, and antioxidant properties of Thymus daenensis Celak. Ind crop prod 2018;121:434-40.

7. Carreón-Abud Y, Torres-Martínez R, Farfán-Soto B, et al. Arbuscular mycorrhizal symbiosis increases the content of volatile terpenes and plant performance in Satureja macrostema (Benth.) Briq. Bol Latinoam Caribe Plant Med Aromat 2015;14.

8. Oliveira RS, Ma Y, Rocha I, et al. Arbuscular mycorrhizal fungi are an alternative to the application of chemical fertilizer in the production of the medicinal and aromatic plant Coriandrum sativum L. J Toxicol Environ Health Part A 2016;79:320-8.
9. Wicaksono WA, Sansom CE, Jones EE, et al. Arbuscular mycorrhizal fungi associated with Leptospermum scoparium (mānuka): effects on plant growth and essential oil content. Symbiosis 2018;1-12.

10. Hossaini SM, Aghaalikhani M, Sefidkon F, et al. Effect of Vermicompost and planting pattern on oil production in Satureja sahendica L. under Competition with pigweed (Amaranthus retroflexus L.). J Essent Oil Bear Plant 2016;19:606-15.

11. Dube L, Naidoo KK, Arthur GD, et al. Regulation of growth, nutritive, phytochemical and antioxidant potential of cultivated Drimiopsis maculata in response to biostimulant (vermicompost leachate, VCL) application. Plant Growth Regul 2018;86:433-44.

12. Oloyede FM. Growth, yield and antioxidant profile of pumpkin (Cucurbita pepo L.) leafy vegetable as affected by NPK compound fertilizer. J Soil Sci Plant Nut 2012;12:379-88.

13. Bremner JM, Mulvaney CS. Nitrogen-total 1. Methods of soil analysis. Part 2. Chemical and microbiological properties, (methodsofsoilan2), 1982. pp. 595-624.

14. John MK.. Colorimetric determination of phosphorus in soil and plant materials with ascorbic acid. Soil Sci 1970;109: 214-20.

15. Nelson DW, Sommers LE. Total carbon, organic carbon, and organic matter. Meth soil anal part 3-chem meth (methodsofsoilan3) 1996;961-1010.

16. Medina MB. Determination of the total phenolics in juices and superfruits by a novel chemical method. J Funct Food 2011;3:79-87.

17. Zhishen J, Mengcheng T, Jianming W. The determination of flavonoid contents in mulberry and their scavenging effects on superoxide radicals. Food Chem 1999;64:555-9.

18. Brand-Williams W, Cuvelier ME, Berset CLWT. Use of a free radical method to evaluate antioxidant activity. LWT-Food Sci Technol 1995;28:25-30.

19. Yourtchi MS, Hadi MHS, Darzi, MT. Effect of nitrogen fertilizer and vermicompost on vegetative growth, yield and NPK uptake by tuber of potato (Agria CV.). Int J Agr Crop Sci 2013;5:2033.

20. Weldegebriel R, Araya T, Egziabher YG. Effect of NPK and blended fertilizer application on nutrient uptake and use efficiency of selected sorghum (Sorghum bicolor (L.) Moench) varieties under rain-fed condition in Sheraro District, northern Ethiopia. Momon Ethiop J Sci 2018;10:140-56.

21. Singh M, Wasnik K. Effect of vermicompost and chemical fertilizer on growth, herb, oil yield, nutrient uptake, soil fertility, and oil quality of Rosemary. Comoun Soil Sci Plant 2013;44:2691-700.

22. Arancon NQ, Edwards CA, Bierman P. Influences of vermicomposts on field strawberries: Part 2. Effects on soil microbiological and chemical properties. Bioresource Technology 2006;97:831-40.

23. Cai, Y., Luo, Q., Sun, M., Corke, H. Antioxidant activity and phenolic compounds of 112 traditional Chinese medicinal plants associated with anticancer. Life Sci 2004;74: 2157-84.

24. Khairy HM, El-Sheikh MA. Antioxidant activity and mineral composition of three Mediterranean common seaweeds from Abu-Qir Bay, Egypt. Saud J biol sci 2015;22(5): 623-630.

25. Theunissen J, Ndakidemi PA, Laubscher CP. Potential of vermicompost produced from plant waste on the growth and nutrient status in vegetable production. Int J Physic Sci 2010;5:1964-73. 
26. Uttara B, Singh AV, Zamboni P, et al. Oxidative stress and neurodegenerative diseases: a review of upstream and downstream antioxidant therapeutic options. Current neuropharm 2009;7:65-74.

27. Besharati H. Effects of sulfur application and Thiobacillus inoculation on soil nutrient availability, wheat yield and plant nutrient concentration in calcareous soils with different calcium carbonate content. J Plant Nut 2017;40:447-56.
28. Motior, MR, Abdou AS, Al Darwish FH, et al. Influence of elemental sulfur on nutrient uptake, yield and quality of cucumber grown in sandy calcareous soil. Aus J Crop Sci 2011;5:1610-5.

29. Najafian S, Zahedifar M. Antioxidant activity and essential oil composition of Satureja hortensis L. as influenced by sulfur fertilizer. J Sci Food Agr 2015;95:2404-8.

30. Abad MJ, Bedoya LM, Apaza L, et al. The Artemisia L. genus: a review of bioactive essential oils. Molecul 2012;17:2542-66. 